\title{
Application of Water-Saving Irrigation Technologies in Minority Areas of
}

\author{
Xinjiang \\ Chenchen $^{1}$, Shi Jing ${ }^{1}$ \\ ${ }^{1}$ Tarim University, Xingjiang alar, 843300
}

KEYWORDS: Water Saving; Irrigation Technology; Xinjiang

\begin{abstract}
With the rapid development of economic and society, the conflict between demand and supply of water is becoming increasingly evident, and water reservation is inevitable. In Xinjiang minority areas, the agricultural water consumption accounts for $97 \%$ of total water consumption, so the key lies in agricultural water-saving irrigation technology. First of all, we investigate the application status of water-saving irrigation technology in Xinjiang, and then propose zoning methods and development mode, to better promote water-saving irrigation in Xinjiang.
\end{abstract}

\section{Introduction}

Xinjiang is one of the most famous arid regions in China, with typical inland arid climate. The Taklimakan desert is located in the southern Xinjiang. The average annual rainfall is only $147 \mathrm{~mm}$ in Xinjiang, while annual average evaporation potential is up to about $2000 \mathrm{~mm}$, so it belongs to a typical desert oasis. The agricultural production mainly depends on irrigation, and $97 \%$ of total water consumption is used in agriculture. Xinjiang is also China's most important commodity cotton production base and petrochemical base. With the implementation of the western development strategy, economic development and population increase, industrial and agricultural water consumption is increasing rapidly, which brings a sharp contradiction between water supply and demand, and causes a great threat to the fragile ecological environment. For this reason, to vigorously promote the development of advanced water-saving irrigation technology has become the key to sustainable use of water resources in Xinjiang.

\section{Application Status of Water-saving Irrigation Technology in Xinjiang}

At present, spray irrigation, micro irrigation and canal seepage control have become the most important water saving technologies in Xinjiang. According to the statistics, by the end of 2014, Xinjiang has irrigated 9.2 million acres with water-saving technology of spray irrigation, micro irrigation and canal seepage control.

In Xinjiang minority areas, 8 million acres of water-saving irrigation project has been started, as the first of the four major projects in the western development. In particular, film trickle irrigation has been applied in desert, Gobi, wasteland district, and achieved good results.

As for the introduction and application of large scale modern sprinkling irrigation equipment, Xinjiang water resources department introduced 2 large sprinklers in 1979 from the United States, and carried out a lot of experiments. Various water-saving irrigation technologies were also 
popularized into application. Fixed and semi fixed pressure sprinkler irrigation is applied throughout Xinjiang province.

By the late of the 90's, the introduction of sprinkler irrigation equipment appeared climax. According to an uncompleted statistic, large sized irrigation equipment in Xinjiang has been up to 400 , as well as tens of thousands of medium and small sized sprinkler irrigation machines.

To some extent, the introduction and promotion of the advanced water saving equipment has promoted the development of the water-saving irrigation in Xinjiang, especially the development of sprinkling irrigation water-saving technology. However, the introduction of these water-saving devices also showed some problems cannot be ignored. About $1 / 3$ of the introduced large sprinklers are shelved; and 1/3 of medium sprinklers don't work. The main reason is that the parameters of sprinkler are difficult to meet the irrigation needs of local crops, so the irrigation quality is unsatisfactory.

\section{Water-saving Irrigation Zoning in Xinjiang}

To promote water-saving irrigation, the techniques and measures taken are closely related to the natural conditions, social and economic conditions, water and soil resources of irrigation districts. The concrete principles of water-saving irrigation zoning are as follow:

a) Climate, topography and other natural conditions are basically the same or similar;

b) Water resources and utilization means, water saving irrigation way are essentially the same;

c) Coordinated with the existing development plan of the whole Xinjiang water resources;

d) County-level administrative boundaries as the basic unit, take due account of the integrity of drainage networks and large-scale irrigation areas;

e) Existing conditions for agricultural production and development prospects are similar.

According to the characteristics of the ethnic minority areas in Xinjiang, determine the characteristic index of zoning through expert experience, and assign the grade point value $\left(\beta_{\mathrm{i}}\right)$ and weight value $\left(\rho_{\mathrm{i}}\right)$ to the characteristic index, as shown in table 1 :

Table 1. Empirical analysis index for zoning

\begin{tabular}{|c|c|c|c|c|}
\hline $\begin{array}{c}\text { Index } \\
\text { level }\left(\beta_{\mathrm{i}}\right)\end{array}$ & $\begin{array}{l}\text { Climate feature } \\
\text { index }(k, \rho=40)\end{array}$ & $\begin{array}{c}\text { Topographic } \\
\text { features }(\rho=10)\end{array}$ & $\begin{array}{l}\text { Water shortage } \\
\text { index }(\beta, \rho=40)\end{array}$ & $\begin{array}{l}\text { Type of irrigation } \\
\qquad(\rho=10)\end{array}$ \\
\hline $\begin{array}{c}\text { I (4 } \\
\text { points) }\end{array}$ & $k>20$ & Mountain basin & $\beta<2$ & $\begin{array}{c}\text { Lead, well and } \\
\text { storage irrigation }\end{array}$ \\
\hline $\begin{array}{c}\text { II (3 } \\
\text { points) }\end{array}$ & $10<\mathrm{k} \leqslant 20$ & $\begin{array}{c}\text { Mountain } \\
\text { alluvial plain }\end{array}$ & $2 \leqslant \beta<3$ & $\begin{array}{c}\text { Lead and storage } \\
\text { irrigation }\end{array}$ \\
\hline $\begin{array}{c}\text { III (2 } \\
\text { points) }\end{array}$ & $5<\mathrm{k} \leqslant 10$ & Alluvial fan plain & $3 \leqslant \beta<4$ & $\begin{array}{c}\text { Lead, well and } \\
\text { pumping irrigation }\end{array}$ \\
\hline $\begin{array}{l}\text { IV (1 } \\
\text { point) }\end{array}$ & $k \leqslant 5$ & Valley plain & $\beta \geq 4$ & Lead irrigation \\
\hline
\end{tabular}

Then calculate the climate features, topographic features, water shortage index and type of irrigation of each area. And based on the water-saving irrigation zoning principle and calculation results, divide Xinjiang into six water-saving irrigation zones. The empirical index and their ranges of the six zones are: Zone I 400 350; Zone II 330; Zone III 320 280; Zone IV 270 260; Zone V 240 210; Zone VI 160 100. 
Combined with the results of agricultural regionalization and water resources division, and taking into account integrity of the prefecture level administrative divisions, adjust the zoning accordingly, and obtain the water-saving irrigation zoning results, as shown in Table 2:

Table 2. Xinjiang water-saving irrigation zoning results

\begin{tabular}{|c|c|c|c|c|}
\hline Zoning & Zoning type & Containing region & Topography & Type of irrigation \\
\hline Zone I & $\begin{array}{l}\text { Drought and water } \\
\text { shortage }\end{array}$ & $\begin{array}{l}\text { Turpan, Hami } \\
\text { Basin }\end{array}$ & Basin & $\begin{array}{l}\text { Lead, well and } \\
\text { storage irrigation }\end{array}$ \\
\hline Zone II & $\begin{array}{l}\text { Drought and water } \\
\text { shortage }\end{array}$ & $\begin{array}{l}\text { North of Kunlun } \\
\text { Mountain }\end{array}$ & $\begin{array}{l}\text { Alluvial fan } \\
\text { plain }\end{array}$ & $\begin{array}{l}\text { Lead and storage } \\
\text { irrigation }\end{array}$ \\
\hline Zone III & $\begin{array}{l}\text { Drought and slight } \\
\text { water shortage }\end{array}$ & $\begin{array}{l}\text { South of Tianshan } \\
\text { Mountain }\end{array}$ & $\begin{array}{l}\text { Alluvial fan } \\
\text { plain }\end{array}$ & $\begin{array}{l}\text { Lead, well, storage } \\
\text { and pumping } \\
\text { irrigation }\end{array}$ \\
\hline Zone IV & $\begin{array}{l}\text { Drought and water } \\
\text { shortage }\end{array}$ & $\begin{array}{l}\text { North of Tianshan } \\
\text { Mountain }\end{array}$ & $\begin{array}{l}\text { Mountain } \\
\text { alluvial plain }\end{array}$ & $\begin{array}{l}\text { Lead, well and } \\
\text { storage irrigation }\end{array}$ \\
\hline Zone V & $\begin{array}{l}\text { Drought and slight } \\
\text { water shortage }\end{array}$ & $\begin{array}{l}\text { Frontal Basin, } \\
\text { valley plain }\end{array}$ & Basin; plain & $\begin{array}{l}\text { Lead and storage } \\
\text { irrigation }\end{array}$ \\
\hline Zone VI & $\begin{array}{l}\text { Drought and water } \\
\text { abundance }\end{array}$ & Valley plain & Plain & $\begin{array}{l}\text { Lead and storage } \\
\text { irrigation }\end{array}$ \\
\hline
\end{tabular}

\section{Water-saving Irrigation Development Mode}

This zone is located in the east of Tianshan Mountain. It is located in the hot and warm dry regions, with average annual precipitation less than $60 \mathrm{~mm}$, average annual evaporation more than $2700 \mathrm{~mm}$, and belonging to typical arid oasis irrigation agriculture.

Water-saving irrigation development mode in this zone would be: broaden sources of income and reduce expenditure; undertaken canal seepage and supporting projects, to optimize the utilization of canal water and improve irrigation techniques; appropriately promote advanced water-saving irrigation techniques according to local conditions. Improved ground irrigation technology should be introduced to this zone. Especially in well irrigation area, could adopt low pressure pipeline coordinated with film irrigation technology. As for horticultural crops such as grape, micro-irrigation technology is suitable to be applied. However, sprinkler irrigation technique is not suitable for application in this zone.

Zone II belongs to warm temperate dry desert climate. It is windy in spring, with dust or sandstorm; it is hot in summer, annual precipitation less than $70 \mathrm{~mm}$, average annual evaporation more than $1500 \mathrm{~mm}$. Here is rich in land resources, but temporal and spatial distribution of water resources is uneven: quite short of water in spring and frequent droughts in autumn. The level of economic development of this zone is relatively low.

Water-saving irrigation development mode in this zone would be: strengthen the infrastructure of irrigation and water conservancy; ensure adequate water used in sand control engineering; focus on canal system matching and seepage control project; according to the level of economic development, it may be appropriate to develop micro-irrigation and pipe irrigation technology; sprinkler irrigation technique is not suitable for application in this zone.

Zone III is located in the south of Tianshan Mountain and the northwest of the Tarim Basin, including the area of Akesu, Kashi and Kezhou. This zone belongs to the warm climate, annual precipitation less than $100 \mathrm{~mm}$, average annual evaporation more than $2000 \mathrm{~mm}$. 
Water-saving irrigation development mode in this zone would be: strengthen the overall planning and comprehensive management of the river basins; develop and utilize water resources reasonably; make more efforts to transform saving irrigation, with combination of diversion works and drainage works; continue to strengthen the work of canal seepage control and improve irrigation techniques; for the main field crops, could fully implement advanced ground irrigation technology. According to the regional economic strength, promote micro-irrigation technology in horticultural crops planting. Sprinkler irrigation technique is unsuitable to be applied expect the former are of Tianshan Mountain, because there are good self-pressure conditions. As for well irrigation area, should develop low pressure pipe irrigation technology as priority while canal seepage control technology as supplement.

Zone IV is an important economic development zone, belonging to warm climate, annual precipitation less than $300 \mathrm{~mm}$, and average annual evaporation more than $1500 \mathrm{~mm}$. The utilization ratio of groundwater in this zone is high, but the contradiction between agricultural water and urban industry is sharp. So it is urgent to introduce and promote water-saving irrigation techniques based on the existing water resources.

Water-saving irrigation development mode in this zone would be: to facilitate the transition from the primary stage to advance stage that taking sprinkler irrigation, micro-irrigation and low-pressure pipe irrigation as the main means; promote sprinkler irrigation technology in the piedmont alluvial fan zone; promote pipe irrigation technology in well irrigation area; in Karamay City and Downstream alluvial plains, it is unsuitable to promote sprinkler irrigation technology.

Zone V is located in the west and north of Junggar Basin. It is warm climate, annual precipitation more than 200mm, and average annual evaporation less than $1800 \mathrm{~mm}$. Water is often used repeatedly in this zone, and water interannual variability is stable, but distribution of water resources is uneven among the four seasons. The basic construction of the irrigation area is poor, and irrigation technology is backward.

Water-saving irrigation development mode in this zone would be: speed up water saving transformation in irrigation district; improve the seepage prevention and matching of canal system; based on the large area of flat land, vigorously promote the advanced technology to improve the ground irrigation; the horticultural crops is suitable for the development of micro irrigation, while sprinkler irrigation and low pressure pipe irrigation technology could be promoted in well irrigation area.

Zone $\mathrm{V}$ is located in the east and west of Junggar Basin. This zone is of the most precipitation in Xinjiagn. The climate here is cool, with less evaporation, belonging to humid continental temperate climate, annual precipitation more than $250 \mathrm{~mm}$, and average annual evaporation less than $1600 \mathrm{~mm}$. Because of the abundant land resources and good soil quality, it is a very suitable zone to develop agriculture, animal husbandry and forestry. In addition, there are favorable conditions for water resources development, so it is suitable to promote various water-saving irrigation technologies. Should optimize the irrigation canal system matching in this zone, and prevent soil secondary salinization; for efficient economic crops and horticultural crops, could carry out the test and demonstration of sprinkler irrigation and micro-irrigation technology.

\section{Reference}

[1] Liu Z H, Zong W M, Engineering C O, et al. Problems in Extension of Agricultural Water-saving Irrigation Technologies and Countermeasures[J]. Journal of Anhui Agricultural Sciences, 2014. 
[2] Hu C, Li D S. Research of Crop Water-Saving Irrigation Optimization[J]. Applied Mechanics \& Materials, 2015, 737:771-775.

[3] Angold Y V, Zharkov V A, Kalashnikov A A. Water-saving technologies and irrigation facilities[J]. Water Practice \& Technology, 2015, 10(3).

[4] Hedley C B, Knox J W, Raine S R, et al. Water: Advanced Irrigation Technologies[J]. Encyclopedia of Agriculture \& Food Systems, 2014:378-406.

[5] Ren C P, Min D U, Tao L I. Water Saving Irrigation Division Scheme in Yangling[J]. Research of Soil \& Water Conservation, 2002. 